\title{
Effectiveness of debate as a teaching method for bioethics: opinion of undergraduate students after a class session
}

\author{
Princy Louis Palatty ${ }^{1,2}$, Elroy Saldanha ${ }^{3}$, Suresh $\mathrm{Rao}^{4}$, Pratima $\mathrm{Rao}^{4}$, \\ Manjeshwar Shrinath Baliga ${ }^{4}$ \\ ${ }^{1}$ Department of Pharmacology, Amrita Institute of Medical Sciences, Kerala, India. \\ ${ }^{2} \mathrm{Head}$, South India Unit, UNESCO Chair in Bioethics (Haifa), National Chair Curriculum, Indian \\ Program. \\ ${ }^{3}$ Surgical Oncology, Sri Aurobindo Institute of Medical Sciences, Medical College, Indore, Madhya \\ Pradesh. \\ ${ }^{4}$ Bioethics Education \& Research Unit of the UNESCO Chair in Bioethics, at Mangalore Institute of \\ Oncology, Pumpwell, Mangalore.
}

Corresponding Author: Manjeshwar Shrinath Baliga.

E-mail:msbaliga@gmail.com

\begin{abstract}
Teaching bioethics to healthcare students is a difficult task principally because the academic curriculum is very rigorous and the belief in most students, staff and administration is that it is not important for enhancing their career. In our ongoing endeavors of innovative way of teaching Bioethics, we attempted at understanding the opinion of undergraduate students on effectiveness of debate as an effective mode of teaching bioethics in a class room session. Students who volunteered to take part in the debate were requested to speak for and against a bioethical issue which in this case was body image and cosmetic surgery. The other students were participants and observed the proceedings. In the end a structured questionnaire was provided to all students and their opinion was sought on the usefulness of debate as a teaching method in the area of bioethics. The results from this study indicated that debate was enjoyable (54.8), helps maintain attention in class (87.68) and effective in conveying ethical issues (64.39). The other important aspect was that $53.43 \%$ students felt that debate was better than the conventional class room teaching for bioethics. As far as the authors are aware of this is the first study that addresses the usefulness of skit as a teaching method and believe that it could be an effective addendum to conventional teaching method in bioethics and needs to be appropriately incorporated.
\end{abstract}

Key words: Bioethics teaching, debate, body image and cosmetic surgery

\section{INTRODUCTION}

In the recent past, there is a profound feeling in the general public and in the healthcare fraternity that medical care, a noble profession has become materialistic and lead to drastic deterioration in the doctor-patient relationship [1]. This has in turn progressed to loss of public trust in healthcare systems and doctors in specific and has caused multiple untoward ramifications in the society and in fraternity. In fact, when compared to the bygone past, the social pages today regularly contain articles on exploitation of patients, counts of corruption, professional negligence, examples of kickbacks, and illegal dual practice by the doctors [2-6]. All these negative events have earned the 
condemnation by the judiciary and have eroded the trust of general public on medical professionals and hospitals [5-8].

With the prevailing issues not abetting and cause-affect analysis warranted, an in-depth study and analysis by the senior medical educationists have indicated that one of the principal reason for the deterioration of healthcare practice is the lacunae in the form of thorough teaching/training in ethics [1, 9-10]. To further substantiate this, the UN declaration of bioethics and human rights adopted on 19th October 2005 also addresses towards bridging the gap [9-10]. Since then, it is universally accepted that teaching bioethics will have profound influence on the holistic development of the healthcare students and that it has to be an essential component in future medical education [1, 9-10].

However, on the downside, unlike with teaching medical subjects, the pedagogy of ethics is a challenge [1]. This is mainly because unlike core medical subjects, teaching bioethics involves influencing a person's view point, to an extent where it can motivate a positive action in a real-life ethical situation and the mentor should also fostering critical thinking and creative brainstorming when dealing with controversial topics [1]. In lieu of these observations, educationists have now been proposing incorporating and adopting a combination of learning modalities like role plays, debates, skits, mime along with conventional class room and bed side teaching [1.9].

The UNESCO Bioethics South India Unit has been a centre working on teaching and inculcating medical ethics in the undergraduate heath care students. The principal objective in this endeavor has been to create awareness in young minds with innovative teaching techniques and without intensifying the already voluminous academic curriculum. In this effort the unit has also adopted debates, movies, skits, drama and bed side teaching to educate undergraduate students on various complicated aspects in Bioethics. The present study was conducted to ascertain the opinion of students on the usefulness of novel methods in teaching bioethics.

\section{METHODOLOGY}

This is a single centre study and was conducted under the aegis of the UNESCO Bioethics South India Unit at Father Muller Medical College, Mangalore, India in the month of January 2016. The study was a part of a research proposal proposed for the Rajiv Gandhi University of Health Sciences and was carried out after obtaining the approval from the Institutional Ethics committee. The investigators developed this questionnaire with the help of medical educationists, bioethicists and researchers. Emphasis was to have a small questionnaire to enhance maximal participation of the volunteers. The final questionnaire consisted of two sections, the demographic and subject specific questions and filling it took a maximum of 5 minutes.

The study was conducted during a class session assigned to teach bioethics. The students were explained the objective of the study and also that their participation was completely anonymous and voluntary. The topic of debate was on ethical issues on body image and cosmetic surgery was debated by two students one for and one against. The students were distributed a structured questionnaire with a class announcement that their participation was voluntary and that they need not reveal their name or register number on the answer sheet and to maintain their anonymity and to deposit the filled questionnaire in the collection box.

\section{STATISTICAL ANALYSIS}

Data was entered in Microsoft excel and analyzed on the online based Vassar Stats statistical program. All quantitative variables are illustrated through frequency and percentage.

\section{RESULTS}

In the current study the volunteers consisted of 21 males and 52 females. Majority (62) students were from urban areas while 11 were from the rural (Table 1). Most of the students did not read books on bioethics (61), were not members of student bioethics group (44), had no previous experience of attending ethics debate program (41) and never attended any debate in bioethics 
program (64) (Table 2). With regard to the subject related questions, most of the students agreed that debate was enjoyable (54.8), helps maintain attention in class (87.68) and was effective in conveying ethical issues (64.39) (Table 2). The other important aspect was that $53.43 \%$ students felt that debate was better than the conventional class room teaching for bioethics (Table 2).

Table 1: Information on the participants pertaining to bioethics background and interest

\begin{tabular}{|c|c|c|c|c|}
\hline & \multicolumn{2}{|c|}{ Yes } & \multicolumn{2}{c|}{ No } \\
\cline { 2 - 4 } & $\mathrm{N}$ & $\%$ & $\mathrm{~N}$ & $\%$ \\
\hline Do you read books in ethics? & 12 & 16.44 & 61 & 83.56 \\
\hline Are you a member of bioethics: & 29 & 39.73 & 44 & 60.27 \\
\hline Have you attended programs in ethics before this? & 32 & 43.84 & 41 & 56.16 \\
\hline Have you participated in bioethics debate programs before this? & 9 & 12.33 & 64 & 87.67 \\
\hline
\end{tabular}

Table 2: Opinion on Effectiveness of debate as a teaching method for bioethics

\begin{tabular}{|c|c|c|c|c|c|c|c|c|}
\hline \multirow{2}{*}{} & \multicolumn{2}{|c|}{$\begin{array}{c}\text { Strongly } \\
\text { Agree }\end{array}$} & \multicolumn{2}{c|}{ Agree } & \multicolumn{2}{c|}{ Disagree } & \multicolumn{2}{c|}{$\begin{array}{c}\text { Strongly } \\
\text { disagree }\end{array}$} \\
\cline { 2 - 9 } & $\mathrm{N}$ & $\%$ & $\mathrm{~N}$ & $\%$ & $\mathrm{~N}$ & $\%$ & $\mathrm{~N}$ & $\%$ \\
\hline $\begin{array}{c}\text { Debate is a enjoyable mode of } \\
\text { learning }\end{array}$ & 30 & 41.1 & 10 & 13.7 & 30 & 41.1 & 3 & 4.11 \\
\hline I like debate over class teaching & 20 & 27.4 & 18 & 24.66 & 19 & 26.03 & 16 & 21.92 \\
\hline $\begin{array}{c}\text { Debate helps us maintain } \\
\text { attention }\end{array}$ & 49 & 67.13 & 15 & 20.55 & 7 & 9.59 & 2 & 2.74 \\
\hline $\begin{array}{c}\text { Debate is effective in conveying } \\
\text { ethical issues }\end{array}$ & 25 & 34.25 & 22 & 30.14 & 17 & 23.29 & 9 & 12.33 \\
\hline
\end{tabular}

\section{DISCUSSION}

Reports from around the worlds indicate that in most of the educational institutes that teach ethics, emphasis is on the traditional didactic lectures [1]. However, from a pedagogical perspective, unlike that with medical subjects, the teaching of medical ethics and bioethics has been an issue principally because a true ethical dilemma goes beyond a simple "right" or "wrong" answer and arguments are mostly based on differing moral grounds [1]. Also, a healthcare professional's career and life are a challenge that requires considerable innovativeness and adroitness in handling the ethical issues and the teaching imparted to them has to provide them with the necessary knowledge and skill [1].

Preliminary observations are suggestive that the conventional class room teaching by teachers may not be very effective in the teaching of bioethics [11-12]. Under these considerations, doubts persist on what impact the traditional didactic method which is known to be not everlasting will have in teaching of medical ethics. However there has never been clarity on how to achieve the best results as the principal objective in teaching bioethics is to have it set a lasting impact and have the values learnt be an integral part in the healthcare practice of the student/professional.

In the recent past studies have shown that debate was useful in enhancing critical thinking and communication skills [13-16]. Additionally, "Blooms taxonomy also identifies debate as an "affective goal domain" principally because it triggers the students' values, attitudes, or interests and results in better assimilation of the teaching topics [16-18]. In debate two students argue on atleast two sides of an issue and bring up facts and vital points. This academic activity stimulates critical thinking and reasoned argument and can create educational memories that will last a lifetime [16-18].

In this study it was observed that most of the students agreed that debate was enjoyable, helps maintain attention in class, to be better than the conventional class room teaching for bioethics. As far as the authors are aware of there no reports published in the area of debate as a method in 
teaching of bioethics. However previous studies have indicated that debate induces diversity, is fun, to change the pace in teaching and to motivate the participants and the audience alike [19-20] and it to be useful in teaching non structured subjects like ethical reasoning [16, 21]. A well planned and conducted debate helps obtain a better grasp of the topic because, unlike in a class room teaching, the students are allowed to step out of their roles as students and be active participants in the learning process all of which will help them in their personal career and life, which in today's context is important [22].

\section{REFERENCES}

1. El Tarhouny SA, Mansour TM, Wassif GA, Desouky MK. Teaching bioethics for undergraduate medical students. Biomed Res 2017;28 (22):9840-44

2. Sachan D. Tackling corruption in Indian medicine. Lancet 2013;382(9905):e23-4.

3. Jesani A. Professional codes, dual loyalties and the spotlight on corruption. Indian J Med Ethics 2014;11(3):134-6.

4. Jain A, Nundy S, Abbasi K. Corruption: medicine's dirty open secret. BMJ 2014;348:4184.

5. Ward PR, Rokkas P, Cenko C, et al. A qualitative study of patient (dis)trust in public and private hospitals: the importance of choice and pragmatic acceptance for trust considerations in South Australia. BMC Health Serv Res 2015;15:297.

6. Kane S, Calnan M. Erosion of Trust in the Medical Profession in India: Time for Doctors to Act. Int J Health Policy Manag 2016;6(1):5-8.

7. Gilson L. Trust and the development of health care as a social institution. Soc Sci Med 2003;56(7):1453-68.

8. Yan Y. The ethics and politics of patient- physician mistrust in contemporary China. Developing World Bioethics 2018;18:7-15.

9. UNESCO Bioethics Program. The Bioethics Core Curriculum. 2008. [Last accessed on 2018 Dec 01]. http://www.unesdoc.unesco.org/images/0016/001636/163613e.pdf

10. Deshpande SN. The UNESCO movement for bioethics in medical education and the Indian scenario. Indian J Psychiatry 2016;58(4):359-62.

11. Murrell VS. The failure of medical education to develop moral reasoning in medical students. Int $\mathrm{J}$ Med Edu 2014;5:219-25.

12. Manson H. The Need for Medical Ethics Education in Family Medicine Training. Med Ethics 2008;40(9):658-64.

13. Jhaveri KD, Chawla A, Shah HH. Case-based debates: an innovative teaching tool in nephrology education. Ren Failure 2012;34(8):1043-5.

14. Campos-Daniel J, Dias Reis Pessalacia J, Leite de Andrade AF. Interdisciplinary debate in the teaching-learning process on bioethics: academic health experiences. Invest Educ Enferm 2016; 34(2):288-96.

15. Mumtaz S, Latif R. Learning through debate during problem-based learning: an active learning strategy. Adv Physiol Educ 2017;41(3):390-4.

16. Latif R, Mumtaz S, Mumtaz R, Hussain A. A comparison of debate and role play in enhancing critical thinking and communication skills of medical students during problem based learning. Biochem Mol Biol Educ 2018;46(4):336-42.

17. Anderson WL, Krathwohl D, Airasian WP, Cruikshank AK, Mayer ER, Pintrich RP, Raths J, Wittroch CM. A Taxonomy for Learning, Teaching, and Assessing: A Revision of Bloom's Taxonomy of Educational Objectives, 2nd ed., Longman, New York ; 2001.

18. Hall D. Debate: Innovative teaching to enhance critical thinking and communication skills in healthcare professionals. Int J Allied Health Sci Pract 2011;9:3-9.

19. Chun KH, Lee YH. Improvement of debate competence: an outcome of an introductory course for medical humanities. Korean J Med Educ 2016;28(1):87-93.

20. Hartin P, Birks M, Bodak M, Woods C, Hitchins M. A debate about the merits of debate in nurse education. Nurse Educ Pract 2017;26:118-20.

21. Hogan S, Dunne J. Evaluating the Effectiveness of a Focused Debate on the Development of Ethical Reasoning Skills in Pharmacy Technician Students. Am J Pharm Educ 2018;82(6):6280-3.

22. McKneally MF and Singer PA. Bioethics for clinicians: Teaching bioethics in the clinical setting. Canadian Med Assoc J 2001;164:1163-7.

$$
\text { Acknowledgements - Nil; Source of Funding - Nil; Conflict of Interest - Nil }
$$

